NBSIR 85-3226

\title{
Fire Characteristics of Composite Materials - A Review of the Literature
}

James E. Brown Joseph J. Loftus Richard A. Dipert

FIE POPY

Do bu thines

U.S. DEPARTMENT OF COMMERCE

National Bureau of Standards

National Engineering Laboratory

Center for Fire Research

Gaithersburg, MD 20899

Issued August 1986

Supported in part by:

U.S. Department of the Navy aval Sea Systems Command (NAVSEA O5R25)

oc ashington, DC 

FIRE CHARACTERISTICS OF COMPOSITE MATERIALS - A REVIEW OF THE

\section{LITERATURE}

James E. Brown Joseph J. Loftus

Richard A. Dipert

U.S. DEPARTMENT OF COMMERCE

National Bureau of Standards

National Engineering Laboratory

Center for Fire Research

Gaithersburg, MD 20899

Issued August 1986

Supported in part by:

U.S. Department of the Navy

Naval Sea Systems Command (NAVSEA O5R25)

Washington, DC

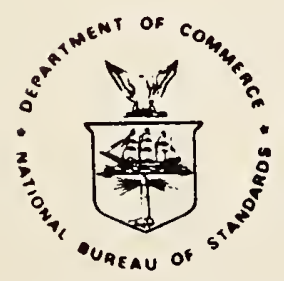

U.S. DEPARTMENT OF COMMERCE, Malcolm Baldrige, Secretary NATIONAL BUREAU OF STANDARDS, Ernest Ambler, Director 

Table of Contents

Page

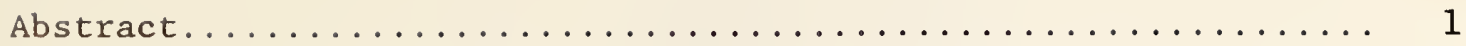

1. Introduction............................. 1

2. Technical Sources of Information.................. 2

2.1 Evaluation of Referenced Materials................. 3

3. Criteria for Evaluation of Composite Materials........... 6

3.1 General Criteria for Choice of Resins.............. 6

3.2 Criteria for Ranking Composites for Fire Resistance........ 7

3.3 Findings from the Literature................. 8

4. Summary .............................. 16

5. Conclusions............................. 17

6. Recommendations and Future Directions............... 17

7. Acknowledgement ........................ 18

8. References............................... 19

Appendix

Technical Information Sources

1. The Defense Technical Information Center.............. 26

2. National Technical Information Service............... 30

3. The Chemical Abstracts...................... 35

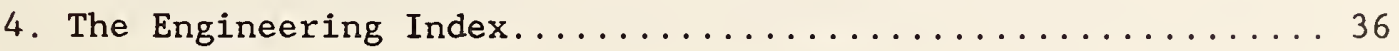

5. Center for Fire Research, Fire Information Service....... 38 



\title{
FIRE CHARACTERISTICS OF COMPOSITE MATERIALS \\ A REVIEW OF THE LITERATURE
}

\author{
James E. Brown \\ Joseph J. Loftus \\ Richard A. Dipert
}

\begin{abstract}
A review is presented of the open literature concerning fire tests of composite materials which may be considered for use in U.S. Navy shipboard structures and installations. Results obtained for thermoplastic resins, thermoset resins, and composite structures are summarized from standard test methods. The methods include tests for limiting oxygen index, smoke production, flame spread, fire endurance, differential scanning calorimetry and thermogravimetric analysis. Typical criteria used by various investigators for ranking materials are discussed, and the material rankings based on test results are given. Data from non-standard tests designed to measure fire performance are also discussed. A detailed review of data and results of tests for selected references is given. Finally, recommendations are made for test developments and for the future direction of the U.S. Navy's fire evaluation program for composites and related materials intended for shipboard use.
\end{abstract}

Key words: flame spread; fiberglass resins; hazard analysis; polymer flammability; reinforced plastics; shipboard fires; thermoplastic resins; thermoset resins.

\section{Introduction}

This report is part of a project to develop an improved capability for predictive fire behavior of composite materials. The initial phase was to conduct a review of the open literature for the Department of the Navy, Naval Sea Systems Command (NAVSEA 05R25), Washington, D.C., for organic matrix composite materials. Composite materials are defined here as combinations of two or more material components present as separate phases and combined to form desired structures that take advantage of certain 
properties of each component. The resin matrix may be a thermoplastic or thermoset polymer; the reinforcement may be graphite, aramid, glass, or other fiber. The Navy's overall objectives are the following:

1. Document information on the fire properties of composite materials.

2. Couple this information with results from small-scale (bench) fire tests conducted by CFR on currently available composite materials.

3. Conduct large-scale fire tests for a broad range of composite materials.

4. Develop a predictive capability for material behavior in fullscale fire tests based on bench-scale tests.

While the Navy's end objectives are focused on the behavior of composites, it was considered that attention had to be given to the properties of neat resins, which are used as the matrices.

\section{Technical Sources of Information}

A computer search of five technical data bases was conducted for fire information on composites and related materials. Table 1 lists these 
sources, the total number of references found, and the number of references found to contain fire information considered pertinent to the Navy's interests.

Table 1. Technical Information Sources

Total No. No. of References of pertinent to

References Navy's interest

Defense Technical Information Center (DTIC)

59

National Technical Information Services (NTIS)

69

63

$668 \quad 15$

Chemical Abstracts* (CA)

Center for Fire Research Library

$\frac{10}{869}$

$\frac{10}{59}$

* 361 journal articles

42 conference reports

265 patents

The 59 references identified are cited in Section 8. Salient findings are extracted and summarized in the appendix to this report.

\subsection{Evaluation of Referenced Materials}

Classification of the pertinent references cited in Table 1 showed that the reports may be divided into three different categories, as shown in Tables 2 , 3, and 4. Table 2 lists those references which contain fire information obtained by standardized test methods and procedures. Table 3 lists those references presenting data obtained by using non-standard fire tests designed specifically to measure a particular fire property of a material. Table 4 identifies those references containing summations of data giving comparisons 
or rankings of different composites and related materials based on fire properties such as oxygen index, smoke, flame spread, and toxicity.

Table 2 - Standard Methods of Test

$\begin{array}{clcl}\begin{array}{c}\text { Sponsoring } \\ \text { organization }\end{array} & \text { Property Tested } & \begin{array}{c}\text { Procedure } \\ \text { identification No. }\end{array} & \text { References } \\ \text { ASTM } & \text { flame spread } & \text { E } 162 & 1,3,4,6,50 \\ \text { ASTM } & \begin{array}{c}\text { oxygen index flammability } \\ \text { test }\end{array} & \text { D } 2863 & 1,4,5,7,19,30,42 \\ \text { ASTM } & \text { smoke (NBS chamber) } & \text { E } 662 & 1,3,6,19,42,50, \\ \text { ASTM } & \text { 25 ft. tunnel-flame spread } & \text { E } 84 & 52,57,58,59 \\ \text { ASTM } & \text { fire endurance test } & \text { E } 119 & 52,53 \\ \text { ASTM } & \text { DSC (polymers) } & \text { D } 3417 & 19,42,23,24 \\ \text { ASTM } & \text { TGA } & \text { D } 3850 & 19,42\end{array}$

Table 3. Specific Fire Tests

$\underline{\text { Test }}$

$1 / 4$ scale room test

heat release

toxicity

$2000^{\circ} \mathrm{F}$ exposure test

lightning (spark test)

burn/blast

burner rig

ballistic test

heat aging, heat stability

melt temperature

anaerobic char

activation energy

\section{$\underline{\text { References }}$}

2

$3,14,17,58$

$6,17,18,19,58$

8

9

10,11

15

21

44

19,42

15,51

20 
$\underline{\text { References }}$

Feasibility of using Kevlar* on shipboard $\quad 12$

Development of thermally stable aircraft panels 13

Improved fiber retention by use of fillers in graphite fiber/ 16 resin matrix composites

New and improved resin systems 25

Prototype rigid polyimide components 26

High-char-yield epoxy curing agents $\quad 27$

Fire dynamics of modern aircraft from a materials point of view 40

Relative fire resistance of select thermoplastic materials $\quad 42$

Flame and smoke management in polyester resin systems 43

Overview, choosing FR resins over iso and other resins 45

GRP** panels - fire code requirements $\quad 46$

Flammability or explosive hazards of GRP $\quad 47$

Survey tests for self-extinguishing and slow burning plastics $\quad 48$

Effects of fiber glass reinforcement on flammability properties 49 of thermoplastics

A proposed rating system to describe the behavior of reinforced 50 plastics in large scale fire tests

Processing and flammability parameters of bismaleimide and some 51 other thermally stable resin matrices for composites

Fire performance of glass reinforced polyesters 53

Flammability and smoke measurements on glass reinforced 54 polyester resins

Summary, high toughness resins, high modules design 56 optimization, quality control, failure criteria for composites 


\section{Table 4. Data Summation Reports - continued}

\section{$\underline{\text { References }}$}

Thermal response of composite panels

Thermochemical characterization of some thermally stable thermoplastic and thermoset polymers

* The use of tradenames does not constitute an endorsement of the product by the National Bureau of Standards

$* *$ glass reinforced plastic

\section{Criteria for Evaluation of Composite Materials}

\subsection{General Criteria for Choice of Resins}

Fire performance is just one of the many criteria involved in the choice of resins used in composites. Cost, mechanical properties, chemical and thermal resistance, and ease of processing must also be considered. Given below are some of the strong and weak characteristics for the two major classes of resins.

Thermoplastics - Generic types: nylons, polystyrenes, polyethylenes, polycarbonates, polysulfones, polypropylenes, and styrene/acrylonitriles

advantages - can be easily made with processing time limited only to heating, shaping, and cooling the structure. Can be salvaged and reworked. 
disadvantages - shrinkage and creep problems, low resistance to organic solvents, and low thermal resistance.

Thermosets - Generic types: epoxies, polyesters, imides, amide-imides, imidazoles

advantages - wide range of formulations, high temperature capabilities, good solvent resistance, good mechanical and electrical properties.

disadvantages - exothermic reactions during curing, shrinkage, evolution of volatiles.

\subsection{Criteria for Ranking Composites for Fire Resistance}

Many criteria have been used by various investigators for rating and ranking composite materials for fire performance. Phenomena most frequently considered are:

1. Flammability
a. ability to withstand high radiant energy
b. high ignition temperature
c. low flame spread rate
d. low rate of heat release/fuel evolution/fuel contribution
e. ease of extinguishment
f. no violent reaction in proximity to heat or ignition source

2. Smoke
a. high evolution temperature
b. low optical obscuration;
c. low soot conversion fraction 


\section{Toxicity}
a. high evolution temperature for toxicant
b. low rate of toxic gas released
c. low toxicity of gases

\subsection{Findings from the Literature}

It is beyond the scope of this report to list all the fire data from each of the referenced materials listed in the Appendix; however, an attempt will be made here to highlight results provided by some of the more thorough investigations. Kourtides et al. [59] used standard fire tests, e.g., oxygen index, flame spread, smoke evolution, etc. to develop rankings for thermoplastic and thermoset resins. Table 5 lists a relative fire resistance ranking for 13 materials as indicated by oxygen index.

Table 5. Ranking by Limiting Oxygen Index for Polymers and Composites

LOI at $23^{\circ} \mathrm{C}$

Thermoplastic resins

1. Acrylonitrile-butadiene-styrene 34

2. Polyaryl sulfone (PAS) 36

3. Polyether sulfone (PES) 40

4. 9,9 Bis-(4-hydroxypheny1) fluorene/polycarbonate- 47 poly(dimethyl siloxane) block polymer (BPFC-DMS)

5. Polyphenylene sulfide (PPS) 50

Thermoset resins

1. Epoxy 
Table 5. Ranking by Limiting Oxygen Index for Polymers

and Composites - continued

LOI at $23^{\circ} \mathrm{C}$

2. Phenolic

3. Polyaromatic melamine 30

4. Bismaleimide

Thermoset Composites

1. $40 \%$ epoxy/181 glass cloth

2. 408 phenolic/181 glass cloth 57

3. $40 \%$ polyaromatic melamine/181 glass cloth 42

4. 408 Bismaleimide/181 glass cloth 60

As indicated in Table 5 the bismaleimide was the best performer among the thermosets tested while the polyphenylene sulfide was best among the thermoplastics.

Kourtides et al. [58] reported the use of oxygen index, smoke, and heat release tests to determine the fire properties of sandwich panels used for partitions and walls. (A sandwich panel here means a honeycomb core material covered on both surfaces with a composite panel material.) Table 6 gives rankings ( 1 - best, 4 - worst) for the materials based on an analysis of the data presented in the report. 
Table 6. Order of Ranking of Sandwich Panels by Three Test Methods

$\begin{array}{lll}\text { NBS Smoke } & \begin{array}{c}\text { Oxygen } \\ \text { chamber }\end{array} \text { Index } & \begin{array}{c}\text { Heat Release Rates } \\ \text { (OSU** Apparatus) }\end{array} \\ \text { Systems } & \underline{25 \mathrm{~kW} / \mathrm{m} x} \underline{50 \mathrm{~kW} / \mathrm{m} \chi}\end{array}$

Epoxy

Polyimide

Bismaleimide

Modified Phenolic

Phenolic

$\begin{array}{llll}3 & 1 * & 4 & 4 \\ 1 & 2 & 3 & 1 \\ 2 & 1 * & 2 & 3 \\ - & - & 1 & 2 \\ 4 & 1 * & - & -\end{array}$

* All had the same LOI value

** Ohio State University

- Not Tested

Based on the results in Table 6 , Kourtides concluded the overall ranking in decreasing order of fire resistance was:

$$
\begin{aligned}
& \text { Phenolic } \\
& \text { Polyimide } \\
& \text { Bismaleimide } \\
& \text { Epoxy }
\end{aligned}
$$

Kourtides [57] also conducted oxygen index and smoke tests on graphite composites and, based on these measurements, ranked the materials accordingly, as given in Table 7 .

\section{Table 7. LOI and Smoke Ranking of Graphite Composites}

\section{Composites}

\section{Epoxy}

Phenolic-Xylok*

Bismaleimide A

Phenolic-Novolac*

Polyether sulfone

Polyphenyl sulfone
$\underline{\operatorname{LOI}(8)}$

Smoke Ranking

* The use of tradenames does not constitute an endorsement of the product by the National Bureau of Standards. 
The author also considered mechanical properties in developing an overall ranking for the materials and concluded that:

The phenolic-xylok composite retained its mechanical properties at elevated temperatures where the other resins failed. However, it showed lower mechanical properties at ambient temperatures than the epoxy composites.

The epoxy composite demonstrated the lowest fire resistance properties of all the composites tested as described by LOI.

The phenolic-novolac, polyether sulfone, and polyphenyl sulfone composites exhibited both high oxygen index and low smoke evolution.

Composites made with bismaleimide A exhibited excellent fire resistance properties, low moisture absorption, and excellent ambient temperature mechanical properties. This resin is designed primarily for use as a fire resistant, high char yield resin.

Gilwee et al. [29] ranked thermosetting resin samples according to char yield and oxygen index, as shown in Table 8. 
Table 8. LOI and Char Yield of Thermosetting Resins

Char yield a $800^{\circ} \mathrm{C}$

LOI $(8)$

$\underline{\text { Resin }}$

Room temp. $\quad 100^{\circ} \mathrm{C} \quad 200^{\circ} \mathrm{C} \quad 300^{\circ} \mathrm{C}$

Benzyl

Melamine

Phenolic

Polyimide I

Epoxy
63

58

54

53

10
43

27

25

27

23
36

26

23

26

22
32

25

19

23

18
31

21

13

19

12

It was concluded that:

The LOI of thermosetting resins can be estimated from the char yield as determined by TGA in nitrogen. The LOI values decreased with increasing temperature. The elevated temperature LOI tests provided a convenient and reliable laboratory procedure to give information on the potential flammability behavior of materials.

Ballard et al. [55] conducted radiant panel pyrolysis tests on an epoxy/carbon fiber composite at $25 \mathrm{~kW} / \mathrm{m}^{2}$ in a closed system. Non-flaming and flaming modes produced different gas and aerosol compositions and had different toxic effects. Non-flaming modes produced large quantities of organic aerosols and carbon monoxide. These quantities were not lethal but could hinder escape and may produce long-term toxic effects. The flaming conditions produced hydrogen cyanide in addition to other toxic products. 
Manley and Sidebotham [54] provided information on the relation of glass fiber orientation (in two resin types, isophthalate and bisphenol) to LOI and smoke measurement. Several systems were evaluated and are listed in Table 9:

Table 9. Fiber Orientation in Composites

\begin{tabular}{|c|c|c|c|c|}
\hline \multirow[b]{2}{*}{ Glass Used } & \multirow[b]{2}{*}{ Resin Percent } & \multirow[b]{2}{*}{ Fiber Orientation } & \multicolumn{2}{|c|}{ LOI $(8)$} \\
\hline & & & Isophthalate & Bisphenol \\
\hline none & 100 & & 18.8 & 19.3 \\
\hline chopped strand mat & 74.4 & random & 19.6 & 19.7 \\
\hline spray & 70.4 & random & 19.7 & 19.6 \\
\hline parallel wind & 55.7 & paralle1 & 20.5 & 21.1 \\
\hline parallel wind & 55.7 & perpendicular & 19.5 & 20.6 \\
\hline woven roving & 48.3 & parallel & 21.0 & 20.7 \\
\hline helical wind & 31.7 & perpendicular & 23.6 & 22.3 \\
\hline helical wind & 31.7 & parallel & 20.9 & 21.5 \\
\hline
\end{tabular}

The author found that the LOI values rose linearly as the proportion of fiber increased. Parallel wound fibers had a higher LOI than perpendicularly wound fibers. Smoke results were more variable and did not show any difference attributable to the orientation of the fibers. Specimens cut perpendicular to the direction of the fiber were more flammable and easier to ignite than specimens cut parallel to the direction of the fiber. This difference was related to the extent by which the exposed fibers trap the char. Isophthalate resin is more flammable than the bisphenol; samples of isophthalate containing less than 50 percent glass fiber will continue to burn freely in ambient air. at room temperature. The bisphenol resin produced more smoke than the isophthalate.

Selley and Voccarella [52] investigated controlling flammability and smoke emissions of reinforced polyesters. Glass reinforced laminates measuring $1 / 8$ inch thick containing 30 percent glass were tested in accordance with the 
ASTM E 84 tunnel test, the ASTM E 162 radiant panel test (flame spread) and the smoke density chamber test, ASTM E 662. Results of tests on three sets of material are listed in Table 10.

Table 10. Results of Tests on Reinforced Polyesters

Test Method and Property

ASTM E 162 flame spread index

ASTM E 84 flame spread smoke emission

ASTM E 662 (Smoke Chamber)

Flaming Mode

maximum specific optical density specific optical density at $90 \mathrm{~s}$ specific optical density at $240 \mathrm{~s}$

Non-flaming mode

maximum specific optical density specific optical density at $90 \mathrm{~s}$ specific optical density at $240 \mathrm{~s}$
System*

$\begin{array}{rrr}\text { I } & \text { II } & \text { IV } \\ 75 & 7 & 7 \\ 64 & 23 & 25 \\ 608 & 270 & 268\end{array}$

203

433

264

2.5

18

11

162

245

128

$\begin{array}{rrr}481 & 400 & 350 \\ 1 & 1 & 5 \\ 16 & 45 & 50\end{array}$

* System I - Orthophthalate resin with high alumina trihydrate filler levels

System II - High performance fire retardant system used widely in construction and transportation applications

System IV - A Het acid*/based resin developed specifically for use with patented char-forming agent $\mathrm{Fe}_{2} \mathrm{O}_{3}$.

* The use of tradenames does not constitute an endorsement of the product by the National Bureau of Standards

From these and other data it was concluded that systems II and IV met Class I flammability requirements in the tunnel test, having flame spread indices of 25 or less. Selley stated that the fuel contributions of both systems was 
negligible while smoke emission was less than half that registered by the filled orthophthalate system I.

A comparison of smoke density chamber data showed lower specific optical density from the orthophthalic resin in both the flaming and non-flaming modes than was registered by the conventional fire retardant system II. System IV shows a significant reduction and had the lowest smoke emission characteristics of the three systems. The combination of low flame spread (class I) and low smoke emissions by both the E 84 and E 162 tests qualified system IV for use under Urban Mass Transit Authority (UMTA, DOT) and HUD proposed specifications. No consideration was given to toxicity effects in this investigation.

Park [50] proposed a fire safety rating system for use with fiberglass reinforced plastics (FRP) that would make use of flame spread, smoke development and toxicity measurements. Flame spread would be determined by the E 84 tunnel test and the Factory Mutual Research Corp. room-corner test or Underwriters Laboratory (UL) test method "Flammability Studies of Cellular Plastics and Other Building Materials Used for Interior Finishes". Smoke would be measured by the E 84 smoke developed index and toxicity would be derived from the lethal concentration $\mathrm{LC}_{50}$ value as determined by the Alarie thermal decomposition method $[61]$.

In general, an industry trend is to have multiple tests rather than one specific test which cannot define the total behavior of a material in a 
fire. This is typified by the recommendations by Kourtides and Parker [42] for using a combination of limiting oxygen index, smoke evolution, and toxicity measurements to determine the relative fire resistance of some thermoplastic materials, as shown in Table 11.

Table 11. LOI, Smoke \& Toxicity Ranking of Thermoplastic Resins

Polymer

Relative Fire

Resistance

Polyphenylene Oxide

low

Acrylonitrile Butadiene Styrene

Bisphenol A Polycarbonate (fire retardant)

Chlorinated Polyvinyl Chloride

Bisphenol A Polycarbonate ( non-fire retardant)

Polyarylsulfone

Polyvinylidene Fluoride

Polyvinyl Fluoride

Polyether Sulfone

9,9 Bis(4-Hydroxyphenyl) Fluorene

Polycarbonate-Poly (Dimethylsiloxane)

Polyphenylene Sulfide

high

4. Summary

From 668 references on composite materials, a total of 59 were found to contain fire information on materials pertinent to the Navy's interests. The leading or most used tests were the limiting oxygen index test (ASTM E 2863). 
the smoke density chamber test (ASTM E 662), and the flame spread test (ASTM E 162). The general consensus among the references surveyed was that, among the thermoset materials, bismaleimide and phenolic matrices were among the best performers in the bench-scale fire tests and that epoxies were among the lowest ranking. Polyphenylene sulfide performed well among the thermoplastic materials tested.

\section{Conclusions}

Results of this survey clearly indicate that investigators primarily limited their evaluation of composites to common small scale or bench type fire tests. While results of these small scale tests are informative and useful for exploratory purposes, we conclude that results from such tests can be misleading without full-scale test studies to validate them. Validated procedures for testing potential shipboard composites are not yet available in the open literature. The majority of the tests cited are known to be poor predictors of full-scale performance in other applications. Thus, it will be necessary to focus only on those bench-scale tests which have been seen to lead to successful full-scale fire predictions in existing applications, such as rate of heat release.

\section{Recommendations and Future Directions}

Based on project studies so far, CFR recommends to NAVSEA that candidate composite materials proposed for shipboard use be first evaluated by the new, promising bench-scale test method, the cone calorimeter [60]. Measurements 
with this test procedure have been shown to correlate well to full-scale results in several applications [62]. The properties examined should include heat release rate and smoke measurement, along with data on ignitability. Promising materials can then be selected. In the next phase, NAVSEA will develop suitable design fire scenarios and criteria. CFR will then formulate an appropriate program for full-scale testing. These full-scale tests are envisioned to be mockups or sectional mockups of the appropriate shipboard fire scenarios. When completed, the full-scale tests will not only serve to evaluate the initial material choices, but will also validate the bench-scale test protocol and permit most future testing pertinent to these scenarios to be done in bench-scale.

\section{Acknowledgement}

This study was supported in part by and was performed as part of a Naval Sea Systems Command Special Forces Program on Composites for Ship Applications. The NAVSEA point of contact was Mr. Charles F. Zanis (Sea 05R25). Technical support was furnished by Messrs. T. F. White and W. Dunham, Naval Sea Systems Command, and Mr. J. G. Morris, David Taylor Naval Ship Research and Development Center. The contract was administered by the Naval Research Laboratory; Dr. Irvin Wolock was the Technical Monitor. 


\section{References}

The Defense Technical Information Center (DTIC)

(1) Technical Report

1980 Materials Characterization Test Program. ASTM Flammability and Fire Shielding Tests for Candidate Kevlar-Reinforced (KRP) Armor for the DDG933 Class of Ships, Naval Surface Weapon Center, Dahlgren, VA AD-B051321L

(2) Smith, B. D.;

1982 Materials Characterization Program; Quarter-Scale Fire Tests; Kevlar Heat Stress Panel Integrity Tests, Naval Surface Weapon Center, Dahlgren, VA

AD-B069630L

(3) Smith, B. D., Garrison, J.M. ;

1981 Flammability and Potential Heat Release for Kevlar-Reinforced Plastic (KRP) for Armored Radomes, Waveguides and Cable Guides, Naval Surface Weapons Center, Dahlgren, VA

AD-B061000L

(4) Silvergleit, M.; Morris, J.G.; LaRosa, C.N.;

1977 Flammability Characteristics of Fiber-Reinforced Matrix Composites, David Taylor Naval Ship Research and Development Center Annapolis, MD, Materials Dept.

AD-B-019020L

(5) Macalone, D.P.; Dowling, R.P.; Bergquist, P.R.;

1983 Flammability Characteristics of Some Epoxy Resins and Composites, Army Materials and Mechanics Research Center, Watertown, MA AD-A135282

(6) Wilhelmi, G.F.;

1975 Glass Reinforced Plastic Piping Systems for 2000 Ton Surface Effect Ship, David Taylor Naval Ship Research and Development Center, Bethesda, MD AD-B034147L

(7) Technical Memo

1967 Flame Resistance Properties of GRP and Wood. Technical Program on GRP for Large Boat Construction, Naval Applied Sclence Laboratory, Brooklyn, NY AD900022L

(8) Diepembrock, J.;

1973 Polyimide Fiberglass Composites Fireproof Tests, Boeing Co. Wichita Div. - Wichita, KS

AD-B003786L 
(9) 01son, G.0.; Force, R.D., Lanba, J.T.;

1980 Ignition Hazard Study of Advanced Composite Free Tank, Boeing Military Airplane Co., Seattle, WA $\mathrm{AD}-\mathrm{B} 048459 \mathrm{~L}$

(10) Musselman, K.A., Babinsky, T.C.;

1979 Burn/Blast Test for Boron-Tungsten Composites, Naval Surface Weapons Center, Dahlgren, VA $\mathrm{AD}-\mathrm{B} 044568 \mathrm{~L}$

(11) Babinsky, T.C., Musselman, K.A;

1978 Burn/Blast Test of Aircraft Structural Elements, Naval Surface Weapons Center, Dahlgren, VA AD-B033711L

(12) Smith, B. D.; Mannschneck, W.A.; Crider, J.F.; Mullelman, K.A.

1977 The Feasibility of Kevlar Composite Armor for Protection of Naval Ships, Naval Surface Weapons Center, Dah1gren, VA AD-C009625L

The National Technical Information Services (NTIS)

(13) Arnold, D.B.; Burnside, J.V.; Hajari, J.V.;

1976 Development of Lightweight Fire Retardant, Low Smoke, High Strength, Thermally Stable Aircraft Floor Paneling, Boeing Commercial Airplane Co., Seattle, WA N76-24365/8

(14) Bowles, K.J.

1980 Fire Test Method for Graphite Fiber Reinforced Plastics, NASA Lewis Research Center N80-18107/6

(15) Cavano, P. J.;

1979 Second Generation PMR Polyimide/Fiber Composites, TRW Equipment Laboratories, Cleveland, $\mathrm{OH}$ N80-12118/9

(16) Gluyas, R. E.; Bowles, K. J.;

1980 Improved Fiber Retention by the Use of Fillers in Graphite Fiber/Resin Matrix Composites, NASA - Lewis Research Center N80 - 13171/7 
(17) Kanakia, M.D., Switzer, W.G. ; Hartze11, G.E.; Kaplan, H.L.;

1980 Fire Test Methodology for Aerospace Materials. 1: Thermal and Smoke Toxicological Assessment of Graphite/Bismaleimide and Graphite/Epoxy Systems, Southwest Research Institute - Dept. of Fire Technology, San Antonio, TX N81-26185/1

(18) Kourtides, D. A.

1983 Fire Resistant Films for Aircraft Applications, NASA - Ames Research Center, Moffett Field, CA N83-22320/6

(19) Kourtides, D.A.; Parker, J. A., Hilado, C.J.

1976 Thermoplastic Polymers and Improved Fire Safety, NASA - Ames Research Center, Moffett Field, CA N77 $-14206 / 5$

(20) Kubin, R.F.

1979 Thermal Characteristics of 3501-6/AS and 5208/T300 Graphite Epoxy Composites, Naval Weapons Center, China Lake, CA AD - AG71067/3

(21) Schlitz, R.J.

1980 Investigation of the Structural Degradation and Personnel Hazards Resulting from Helicopter Composite Structures Exposed to Fires and/or Explosions, Bell Helicopter, Textron, Fort Worth, TX $\mathrm{AD}-\mathrm{A} 104757 / 0$

(22) Son, Byung Chan

1973 Fire Endurance Test of a Fiber Glass Reinforced Polyester Double Wall Assembly, National Bureau of Standards, Washington, DC PB-221184/5

(23) Son, Byung Chan

1972 Fire Endurance Test of a Fiberglass Reinforced Polyester Resin Wall Assembly, National Bureau of Standards, Washington, DC PB - 214784/1

(24) Williamson, R.B.; Baron, F.M.

1971 Fire Test of Fiberglass Reinforced Plastic Structural Wall Panel, University of California at Berkeley - Structural Engineering Laboratory, Berkeley, CA $\mathrm{PB}-222900 / 3$

(25) Wolock, I.

1973 Conference Report on New and Improved Resin Systems Office of Naval Research, London $\mathrm{AD}-780485 / 9$ 
(26) Wykes, D.H.

1975 Prototype Rigid Polyimide Components, Rockwell International Corp. - Space Division, Downey, CA $\mathrm{AD}-780485 / 9$

(27) 1981 High-Char-Yield Epoxy Curing Agents, National Aeronautics and Space Administration, Washington, DC PB81-971049

Chemical Abstracts (CA)

(28) Hecht, J.L.

1982 New Flame-retarded Glass Reinforced Polyethylene Terephthalate Resins, Plastics Technology, Vol.18, No.1, pp. 109-122

(29) Gilwee, W.J.; Parker, J.A.; Koutides, D.A.

1980 Oxygen Index Tests of Thermosetting Resins, Journal of Fire and Flammability, Vol.II, No.1, pp. 22-31

(30) Parvin, K.;

1979 Fire Performance of Glass Reinforced Polyesters, Fire and Materials, Vol.3, No.4, pp. 218-222

(31) Gagliani, J., Lee, R.; Sorathia, U.A.K.; Wilcoxson, A.L.

1980 Development of Fire-Resistant, Low Smoke Generating, Thermally Stable End Items for Commercial Aircraft and Spacecraft Using Basic Polyimide Resin, NASA (Contract Rep)-CR-160576, SR79-R04674-38, p. 176

(32) Gilwee, W.J. et al.

1976 Fire Resistant Low Density Composites - High Performance Plastics, National Technical Conference, Soc. Plast. Eng., Vol. 43, p. 6

(33) Watanable, T.; Soto, M.; Kumagima, H.

1982 High Current DC Arc Ignition Testing of Glass Reinforced Plastics Composites Vol. 13 No. 1; pp. 24-28

(34) Haines, P.J.; Leven, T.J.; Skinner, G.A.

1982 A Study of Flame Retarded Polymers by Thermal Methods Thermochem. Vol. 59 No. 3, pp. 331-342

(35) Chanilik, B.V.

1979 Chemical Resistant Flame Retardant FRP

Aust. Plast. Rubber, Vol. 30-31 N: 12-1, Page 11 
(36) Dean, T.C.; Johnson, D.B.; Cooper, F.

1977 The Use of Antimony Trioxide in Flame-retardant Glass-reinforced Polyester for the Boat-building and Construction Industries Plastic and Rubber Mater. App1. Vo1. 2 No. 2, pp. 71-76

(37) Schaper, K.L.

1981 Toxicity of Fiberglass Reinforced Plastics Build Contents-Real Fire Probl., Fall Conf. Fire Retardant Chemical Assoc. pp. 53-62

(38) Kumar, D.; Faklen, G.M. ; Parker, J.A.

1984 High-strength Fire and Heat-resistant Imide Resins Containing Cyclotriphosphazene and Hexafluoroisopropylidene Groups

Polymer Sci.; Polym. Chem. Ed. Vol. 22 No. 4, pp. 927-943

(39) Amembol, A.

1976 Fire Retardant Analysis of an FRP Composite Before and After the Tunnel Test

J. Fire Retard. Chem. Vol. 3 No.1, pp. 22-33

(40) Parker, J.A.; Kourtides, D.A.; Fisk,R.H.; Gilwee, W.J. 1983 New Fireworthy Composites for Use in Transportation Vehicles Fire Sciences, Vol. 1, pp. 432-458

(41) Theberga, J.E.

1972 Flammability Resistance of Glass Fortified Thermoplastic Resins Soc. Plast. Eng., S. Calif. Sect, March 27, pp. VIII, $1 \& 5$

\section{The Engineering Index}

(42) Kourtides, D.A.; Parker, J.A.

1978 The Relative Fire Resistance of Select Thermoplastic Materials Plastics Design and Processing, Vo1. 18, No. 4, pp. 53-63

(43) Keating, J.Z.,

1977 Flame and Smoke Management in Polyester Resin Systems

Reinf. Plast. Compos. Inst.,

32nd. Ann. Conf. Proc.

SPI, New York, NY, Sect. 13-F, p. 7

(44) Turpock, H.S., McQuarrie, T.S.; Chan, R.M. ; Gunderson, K.W.

1977 High Temperature Properties of Fire Retardant and Corrosion Resistant FRP

Reinf. Plast. Compos. Inst.,

32nd. Ann. Conf. Proc.

SPI, New York, NY, Sect. 5-C, p. 15 
(45) Trampenau, R.H.; Wilson, T.B.

1975 Use of Fire Retardant Polyester in Willard Boat Works 120 Foot Motor Vessel

Reinf. Plast. Compos. Inst.,

30th. Ann. Conf. Proc.

SPI, New York, NY, Sect. 2-E, P. 7

(46) Trampenau, R.H.; Fire Retardant FRP in Construction

SPE, Annu. Tech. Conf., 31st, Pap, Montreal, Que., pp. 680-684

(47) Fuller, R.B.; Jensen, J.D.

1973 Plastic Fiber Glass Operations

Fire Techno1, Vol. 9, No. 2, May 1973, pp. 101-111

(48) Baron, A.L.; Fried, W.T.; McNally, D.

1972 Self-Extinguishing Celanex - A Remarkable New High Performance Engineering Thermoplastic

SPE, Reg. Tech. Conf. (Advances in Reinforced Thermoplastics), Tech paper for meet (Calif. Sect), March 27, 1972, Session IX, pp. $15-421 ; 817$

(49) Hattori, K.

1969 Effects of Fiber Glass Reinforcement on Flammability Properties of Thermoplastics

SPE, Reg Tech Conf, Tech pap (Western New England Sec) pages 9-13 421: 817

(50) Park, R. E.

1983 A Proposed Rating System to Describe the Behavior of Reinforced Plastics in Large Scale Fire Tests

ASTM STP 816 E. L. Schaffer, Ed., American Society for Testing and Materials, 1983, Pp. 107-113

(51) Kourtides, D. A.

1984 Processing and Flammability Parameters of Bismaleimide and Some Other Thermally Stable Resin Matrices for Composites

Polymer Composites, Vol. 5, No. 2, pp. 143-150

(52) Selley, J.E., and Voccarella, P. W.

1979 Controlling Flammability and Smoke Emissions in Reinforced Polyesters

Plastics Engineering, Vo1. XXXV, No. 2, pp. 43-47

(53) Parvin, K.

1979 Fire performance of Glass Reinforced Polyesters Interflam 79, Guildford, UK, March 1979

(54) Manley, T.R., and Sidebotham, S.

1977 Flammability and Smoke Measurements on Glass Reinforced Polyester Resins

Fire Research, Vol. 1, No. 2, pp. 97-100 
(55) Ballard, R. et al.

1980 Radiant Panel Tests on Epoxy/Carbon Fiber Composites NASA Technical Memorandum 81185

(56) Poranski, C.F.

1984 High Performance Composites and Adhesives for V/STOL Aircraft NRL memorandum report 5231

(57) Kourtides, D. A.

1980 Graphite Composites with Advanced Resin Matrices AIAA/ASME/ASCE/AHS 21st Structures, Structural Dynamics and Materials Conference, May 12-14, 1980, Seattle, WA

(58) Kourtides, D.A. et al.

1979 Thermal Response of Composite Panels

Polymer Engineering and Science

Vo1. 19, No. 3, pp. 226-231

(59) Kourtides, D.A. et al.

1979 Thermochemical Characterization of Some Thermally Stable Thermoplastic and Thermoset Polymers Polymer Engineering and Science

Vol. 19, No. 1, pp. 24-29

(60) Babrauskas, V.

1982 Development of the Cone Calorimeter -- A Bench-Scale Heat Release Rate Apparatus Based on Oxygen Consumption

National Bureau of Standards

Washington, D.C.

NBSIR 82-2611

(61) Alarie, Y.

1981 Toxicity of Thermal Decomposition Products: An Attempt to Correlate Results Obtained in Small Scale and Large Scale Tests Journal of Combustion Toxicology

Vol. 8, Feb. 1981, pp. 58-68.

(62) Babrauskas, V.

1984 Bench-Scale Methods for Prediction of Full-Scale Fire Behavior of Furnishings and Wall Linings. Society of the Fire Prot. Engrs.

Report 84-10, Boston. 
APPENDIX

\section{Technical Information Sources}

\section{The Defense Technical Information Center (DTIC)}

Three reports from the Naval Surface Weapons Center, Dahlgren, VA, deal with Kevlar poly(p-phenylene terephthalate) reinforced plastics (KRP). The first technical report [1] presented fire and flammability test data for three new flexible Kevlar-reinforced plastic (KRP) armors. All three exceeded requirements of MIL-STD-1623B and NAVSEA guidelines with respect to flame spread index, oxygen index and smoke obscuration index--two of them significantly. A conservative $200^{\circ} \mathrm{C}\left(392^{\circ} \mathrm{F}\right)$ maximum service temperature for the KRP insulation interface was recommended for new armors.

In a second report, Smith [2] presents results of quarter-scale fire tests and Kevlar heat-stress panel integrity tests for evaluating flexible KRP. The objective of the tests was to determine the level of protection from fragments, flammability characteristics, resistance to environmental vibration and shock stress of mockup assemblies, and shipyard safety requirements with respect to applying the adhesive, cutting and trimming the KRP panels and cost to install the armor on board ship.

In the third report, Smith and Garrison [3] describe standard flammability and potential heat release tests performed on several new KRP armors developed for radomes; their performance was compared to that obtained for 
early KRP armors. Rigid KRP armor fabricated using polyester resins was recommended for rigid self-supporting, compound curved surface armored radomes.

Silvergleit et al. [4] from the David Taylor Naval Ship Research and Development Center, Annapolis, MD, Materials Department, provide results of tests to determine the flammability characteristics of fiber reinforced organic matrix composites, in which the effects of resin, fiber, and fire retardant additives on flammability were evaluated. Information is presented on flame spread index determined by the radiant panel test, the amount of smoke generated and products of combustion based on the smoke density chamber and the amount of oxygen required to support combustion according to the limiting oxygen index method. Polyimide composites were the most resistant to flame spread and exhibited the lowest evolution of smoke and toxic products. No significant differences in flammability characteristics were observed for the loose polyester and epoxy glass cloth laminates. The addition of antimony trioxide and hydrated alumina to the polyester and epoxy resin systems significantly decreased flammability characteristics but caused a marked increase in smoke evolution. It also was observed that smoke properties were dependent on resin content, while the type of reinforcement did not appear to affect flame spread index or smoke properties. The use of protective barriers or intumescent coatings in selected shipboard areas was suggested to reduce flame spread and length of time for generation of smoke. 
Macaione et al. [5] from Army Materials and Mechanics Research Center, Watertown, MA, determined the flammability characteristics of a number of epoxy resin formulations and glass fiber reinforced epoxy resin composites. These were evaluated by thermal analysis, limiting oxygen index/temperature index, flash ignition, and smoke density measurement techniques. Results indicated that appropriate flame retardant additives or halogenated monomers should be incorporated into the matrix resin to increase material survivability and reduce resin combustibility.

Wilhelmi [6] from the David Taylor Naval Ship Research and Development Center, Bethesda, MD, tested glass reinforced plastic piping systems for 2000 ton surface effect ships. Experiments were conducted with commercially available glass reinforced plastic piping material in the areas of surface flammability; smoke density and toxicity; fire performance under dry, stagnant, and flowing water conditions.

The Naval Applied Science Lab, Brooklyn, NY, in a technical memorandum [7], reported on the flame resistance properties of GRP and wood in a technical study on glass reinforced plastics (GRP) for large boat construction. A FRP laminate fabricated with a fire retardant resin was somewhat lower in ignition time than equivalent material made with general purpose resin but the latter material burned five times longer than the fire resistant type. Soaking in diesel fuel had very little effect on the FRP materials, absorption was minimal, and flame resistance properties were unaffected. 
Diepembrock [8] of the Boeing Co., Wichita Division, made a $2000^{\circ} \mathrm{F}\left(1092^{\circ} \mathrm{C}\right)$ fire test on two polyimide-glass fiber panels consisting of six and 12 plies of structural backing, that had been sealed with polyimide adhesives and six ply acoustical facing. The test structure simulated the inner wall of the fan duct assembly on the FAA/JT30 ground test demonstration nacelle.

Olson et al. [9] from the Boeing Military Airplane Co., Seattle, WA, assessed the ignition hazard of an advanced composite fuel tank. The report presents results of a program to assess the fuel ignition vulnerability of a glass reinforced-epoxy composite wing box in a lightning environment. Concern was with ignition of the GR/EP fabric and tape, fuel fitting to bulkhead sparking, and jointed panel sparking.

Mullelman and Babinsky [10] at the Naval Surface Weapons Center, Dahlgren, VA, conducted burn/blast tests to determine if fibers would be released from boron/tungsten/epoxy laminates. It was found that five percent by weight of free fibers were produced. Burn times of 20 minutes resulted in 20 to 21 percent weight loss.

The same Navy personnel [11] also investigated the effects of fire and explosion on carbon/graphite composite materials used in aircraft structural elements. Tests were conducted in a totally enclosed 244 cubic meter compartment so that all released material could be captured and its dissemination characteristics ascertained. 
Lastly, Smith et al. [12] of the Naval Surface Weapons Center, Dahlgren, VA, determined the feasibility of Kevlar composite armor for protection of Naval ships. This is a confidential report, but distribution can be made to U.S. Government agencies.

\section{National Technical Information Services (NTIS)}

of a total of sixty references found in the National Technical Information Services (NTIS), twenty-two dealt with problems associated with the release of graphite fibers from the composite matrix. A total of seven references were considered pertinent to the Navy's fire interests and these will be discussed here.

Arnold et al. [13] of Boeing Commercial Airplane Co., Seattle, WA, discussed fire resistance and mechanical property tests on sandwich configurations composed of resin-glass fiber laminates bonded with adhesives to Nomex honeycomb cores. Tests were designed to establish whether fire safety of an airplane could be improved without sacrificing mechanical performance of the aircraft floor panels.

Bowles [14] of NASA-Lewis Research Center presented a test method for assessing the burning characteristics of graphite fiber reinforced composites. The method utilizes a modified rate of heat release apparatus. The application of the test to the assessment of composite materials is illustrated for two resin matrix/graphite composite systems. 
Cavano [15] of TRW Equipment Laboratories investigated isothermal aging of graphite fiber, neat resin samples, and composite specimens in air at $326^{\circ} \mathrm{C}$ $\left(600^{\circ} \mathrm{F}\right)$. Exposures at $65^{\circ} \mathrm{C}$ and 97 percent relative humidity were conducted for both neat resin and composites for eight day periods. Anaerobic charring of neat resin and fire testing of composites were conducted. The composites were fire tested on a burner rig developed for the program. Results indicated that neat Polymerization Monomeric Reactants (PMR-2) polyimide matrix resins exhibited excellent isothermal resistance and that PMR-2 composite properties appear to be influenced by thermo-oxidation stability of the reinforcing fiber.

Gluyas and Bowles [16] of NASA-Lewis Research Center tested a variety of matrix fillers for their ability to prevent loss of fiber from graphite fiber/PMR polyimide and graphite fiber/epoxy composites in a fire. Fillers tested included powders of boron, boron carbide lime glass, lead glass, and aluminum. Boron was most effective in preventing loss of graphite fiber during burning. Mechanical properties of composites containing boron filler were measured and compared to those of composites containing no filler.

Kanakia et al. [17] at the Southwest Research Institute made thermal and toxicity tests and smoke assessments for graphite/bismaleimide and graphite/epoxy systems. Both materials showed a high degree of thermal stability, with total heat release values being essentially identical under piloted ignition conditions over a range of 50 to $100 \mathrm{~kW} / \mathrm{m}^{2}$ incident heat flux. In every case the graphite/bismaleimide composite outperformed the 
graphite/epoxy system, e.g., the graphite epoxy material auto-ignited at about $70 \mathrm{~kW} / \mathrm{m}^{2}$, produced about 23 percent higher peak heat release rates, approximately 42 percent more carbon monoxide, and considerably more smoke. Toxicological potencies of smokes produced were also evaluated for 30 minute exposures and were found to be comparable to wood.

Kourtides [18] at the NASA, Ames Research Center, reported on a study of aircraft decorative films for flammability, smoke emission, toxic gas emission, and flame spread.Candidate films were: flame modified polyvinyl fluoride, polyvinylidene fluoride, polyimide, polyamide, polysulfone, polyphenylsulfone, polyethersulfone, polybenzimidazole, polycarbonate, polyparabanic acid, polyphosphazene, polyetheretherketone (PEEK), and polyester. The films which exhibited the highest fire resistance properties were of PEEK, aramide polyamide, and ISO-BPE polyester.

Kourtides et al. [19] also reported on the thermochemical and flammability characteristics of typical thermoplastic materials. Properties studied included melt temperature, enthalpy changes by DSC, TGA in anaerobic and oxidative environments, oxygen index, smoke evaluation, relative toxicity of the volatile products of pyrolysis, and selected physical properties.

Kubin [20] at the Naval Weapons Center China Lake, CA, reported thermal characteristic data for two graphite epoxy composites intended for use as aircraft structural components. Activation energies were found to be 19.7 and $25 \mathrm{kcal} / \mathrm{mole}$, while the heats of reaction for pyrolysis were -18.4 and $-20.4 \mathrm{cal} / \mathrm{g}$ for the composite materials. The kinetic properties were used to 
develop predictions of thermal degradation at flight temperatures. For fire fighting purposes, it was recommended that bulk material temperature be reduced well below $300^{\circ} \mathrm{C}\left(572^{\circ} \mathrm{F}\right)$ to prevent continuation of exothermal pyrolysis reactions. It was also found that differential scanning calorimetry provided a more sensitive test of composite cure than reflectance measurements.

Schlitz [21] at Bell Helicopter Textron, Fort Worth, TX, reported on tests of two helicopter structures: a sheet-stiffened, built-up door of Kevlar-49 fabrics impregnated with epoxy resin, and a honeycomb sandwich fuselage shell structure of graphite/epoxy fabric skins on a Nomex honeycomb core. Tests conducted on materials from these structures were smoke generation and structural degradation tests. Ballistic tests on the complete test structure were conducted to determine whether the structure would ignite under High Energy Impact conditions. A major part of the paper was a literature survey. Based on this survey and testing, design criteria for structural composite components were investigated and, when appropriate, formulated.

Son [22] at the National Bureau of Standards conducted standard fire endurance tests on glass fiber reinforced polyester double wall assemblies. Each wall assembly contained glass fiber-reinforced (GRP) sheet faces glued to a corrugated GRP stiffener core. The GRP core members were painted with an intumescent type fire retardant paint and the core spaces were filled with mineral wool insulation. The wall represented a party wall in single family attached housing and was tested under an applied load of $700 \mathrm{lb}$ per linear ft per wall. 
In another report, Son [23] reported on fire endurance tests of a glass fiber reinforced polyester resin wall assembly with mineral wool fill. Under an applied load of $730 \mathrm{lb}$ per linear $\mathrm{ft}$ (p1f) the wall was subjected to fire tests in accordance with the ASTM E 119 Fire Endurance Test. The time for failure, which occurred by flame-through of the assembly to the unexposed surface, was approximately six minutes. Considerable smoke evolved throughout the fire exposure period.

Williamson and Baron [24] at the University of California, Berkeley, CA, described a fire test of glass fiber reinforced plastic structural wall paneis to determine the performance of a load-bearing glass fiber reinforced polyester wall systems subjected to standard fire conditions in the ASTM E 119. The structural composite was a glass fiber reinforced polyester laminate manufactured from random oriented glass fibers and impregnated with specially formulated polyester resins. The composite contained a large percentage of inorganic fillers. The wall panel passed thermal requirements for a 30 minute load-bearing fire rating.

Wolock [25] provided a conference report on new and improved resin systems. Supported by the Reinforced Plastics Group of the Plastics Institute, the meeting was held in London in 1973. Discussed were fluorinated epoxies, vinyl esters, furanes, polyimides, Friedel-Crafts resins, rubber reinforced resins, and fire retardant resins. In addition, developments in silane coupling agents were discussed and one paper was presented on the effect of water on carbon fiber-epoxy composites. 
Wykes [26] at the Rockwell International Corporation, Downey, CA, provided information on prototype rigid polyimide components. A brief history of high-temperature polyimide resins is given along with a discussion of the properties of DuPont PI 4701 glass laminates. Mechanical and flammability properties of DuPont PI 2501/glass laminates are compared with epoxy, phenolic, and silicone high temperature resin/glass material systems. Off-gassing characteristics are also presented. A discussion is included on the current developments in polyimide materials technology and the potential civilian and government application of polyimide materials to reduce fire hazards and increase the survivability of men and equipment.

A NASA report [27] discussed high char yield epoxy curing agents. Epoxy resins are the most widely used matrix resins in graphite fiber reinforced resin matrix composite materials because they are easy to process and have excellent mechanical properties. When exposed to fire, these composites lose their structural integrity and free graphite fibers are released. A novel class of imide-amine curing agents has been synthesized, which more than doubles the char yield of cured epoxy resins while preserving structural integrity and preventing fiber release.

\section{III: The Chemical Abstracts (CA)}

A review of the Chemical Abstracts data base generated a total of 361 journal articles, 33 technical reports, 42 conference reports, and 265 patents. From all of these a total of 14 items were selected for their contribution to the 
fire and flammability information. These items are numbered 28 to 41 in the Reference listing. Complete abstracts, however, are not available in the computer data base and thus only those reports judged to be highly pertinent were selected and discussed in the text.

\section{The Engineering Index (EI)}

A survey of the Engineering Index (EI) produced a total of 62 references. Fifteen of these were considered pertinent to fire and flammability and of these six were previously cited in the sections above.

Kourtides and Parker [42] studied the thermochemical and flammability characteristics of some typical and advanced thermoplastic materials for use in aircraft interiors. The properties studied were melt temperature, enthalpy by DSC, TGA analyses in oxidative and anaerobic environments, oxygen index, smoke evolution, relative toxicity of volatile products of pyrolysis, and selected physical properties. Test results and relative rankings based on some of the flammability, smoke and toxicity properties are presented. Under these test conditions some of the advanced polymers evaluated were significantly less flammable or toxic than polymers in current use.

Keating [43] described flame and smoke test methods used to determine the relative flammability of polyester formulations. Several typical formulations were checked by each method and the values are reported. The economics of flame and smoke management are discussed and the effect of glass contents, core materials, and methods of fabrication on test results is 
covered. Heavy emphasis is placed on the use of hydrated alumina based fillers and blended resins as the most cost effective tool to meet flammability standards.

Turpock et al. [44] provided heat aging and heat stability data on glass fiber reinforced plastics used in the construction of hoods, ducts, stacks, and other structures. The heat aging data provided information on laminates after continuous exposure to various elevated temperatures up to and including one year in duration. The heat stability data provide information about the physical strength retention of the polyester laminates at various elevated temperatures.

Trampenau and Wilson [45] discussed Willard Boat Works experience with FR resins and reasons for choosing these materials over the more conventional ortho and isophthalate boat resins. The largest GRP boat built in the USA is described. Engineering and technical aspects of constructing the $120 \mathrm{ft}$ vessel are described with special emphasis on innovation design features. Resin and laminate properties, strength retention at elevated temperatures, insulation values, and fire retardant properties are discussed. Work with the American Bureau of Shipping on design criteria for this prototype of a new vessel class is also presented.

Trampenau [46] also discussed the use of GRP panels in buildings in regard to code requirements for flame retardance of building materials. Particular attention was given to testing of reinforced polyester structural members as well as to full scale testing of a two-story panel configuration. Special 
resin development is also included in this report. Several case histories are described and general conclusions are drawn as far as code approval is concerned.

Fuller and Jensen [47] presented a literature review of plastic glass fiber operations and deals specifically with the flammability or explosion hazards of glass fiber reinforced plastics processing.

Baron et al. [48] described the properties, performance, and processing of commercially available molding materials, flame retarded glass-reinforced thermoplastic polyester and poly(butylene terephthalate). Survey tests for self extinguishing, corrosivity, physical, thermal, mechanical, and electrical characteristics, as well as melt viscosity and processability, showed no significant property difference between the standard slow burning and self-extinguishing compositions.

Hattori [49] presented a study on the effects of glass fiber reinforcement on the flammability properties of thermoplastics. Three tests to determine flame retardance are described. Glass fiber reinforced plastics are compared with unreinforced plastic materials, such as polycarbonate, polysulfone, styrene-acrylonitrile copolymer, etc.

\section{Center for Fire Research. Fire Research Information Services}

Park [50] proposed a fire rating system for use with glass fiber reinforced plastics in a paper that covers ignition, flame spread, smoke development, 
and toxicity. The tests chosen for the rating system are described and examples presented of how several different types of FRP sheet perform in these tests. A new class of fire retardant systems was presented, offering a combination of low flame spread, low smoke, and low toxicity. Toxicity data are presented on both large-scale (room burns) and small-scale tests.

Kourtides [51] studied the effect of processing variables on the flammability and mechanical properties of state of the art and advanced resin materials for graphite composites. Resin matrices evaluated included state of the art epoxy, phenolic novolac, phenolic-Xylok, two types of bismaleimides, benzyl polyethersulfone, and polyphenylsulfone. Comparable flammability and thermochemical data on graphite-reinforced laminates prepared with these resin matrices are presented and the relationship of some of these properties to the anaerobic char yield of the resins is described.

Selley and Voccarella [52] cited specific additives that can inhibit flammability by promoting the production of char in the early stages of burning. Flammability was characterized by the ASTM E 84 tunnel test, the ASTM E 162 radiant panel test, and the ASTM E 662 smoke density chamber test, all currently recognized test methods.

Parvin [53] from Great Britain discussed the fire performance of glass reinforced polyesters as determined by simple strip burning tests, BS 476 tests, ASTM E 84 tunnel test, limiting oxygen index, and Australian AS 1530. Results of tests on five different resins are presented. 
Manley and Sidebotham [54], also of Great Britain, discussed flammability and smoke measurements of glass reinforced polyester resins. The effects on flammability and smoke production on the amount and orientation of glass fiber in reinforced polyesters were studied by means of critical oxygen index (COI) method (ASTM D 2863-70) and a smoke chamber test (Stanton FTB). No significant difference were found among resins, but the COI value rose linearly as the proportion of fiber increased. Parallel wound fibers had a higher COI than perpendicularly wound fibers. Smoke results were more variable and did not show any differences attributable to the orientation of the fibers.

Ballard et al. [55] used a radiant panel test chamber to study the effects of pyrolysis of polymeric materials. The thermal response of the sample and composition of gas and aerosol produced were determined. Toxicological effects of the gas and aerosol in the chamber were determined by changes in cardiac action, respiration, blood enzymes and delayed escape responses in animals. Data were presented for pyrolysis of epoxy/carbon fiber composite at $25 \mathrm{~kW} / \mathrm{m}^{2}$. Non-flaming and flaming modes produced different gas and aerosol compositions and different toxic effects. Non-flaming modes produced large quantities of organic aerosols and carbon monoxide. The flaming condition produced hydrogen cyanide, in addition to other toxic products.

Poranski [56] presented a summary of reports designed to develop and characterize high modulus, high toughness resins with use temperatures of 350 to $450^{\circ} \mathrm{F}$ or higher; to develop failure criteria for composite design optimization; and to establish appropriate quality control parameters. 
Kourtides [57] reported on the effect of processing variables on the flammability and mechanical properties of state of the art and advanced resin matrices for graphite composites. Resin matrices included state of the art epoxy, phenolic-novolac, polyethersulfone, and poly(p-phenylene sulfone). Comparable flammability and thermochemical data on graphite-reinforced laminates prepared with these resin matrices are presented and the relationship of some of these properties to the anaerobic char yield of the resins is described.

Kourtides et al. [58] provided information on the thermochemical and flammability characteristics of laminating resins and composites. The high temperature performance of laminating resins, such as modified phenolics, polyimides, and bismaleimides, is compared with the performance of epoxies. The relationship of increased fire safety with the use of polymers with high anaerobic char yield is shown. Processing parameters of the state of the art epoxy resin and advanced resin composites are detailed.

Kourtides et al. [59] studied the thermochemical and flammability properties of some thermally stable polymers. These resins were primarily used in the fabrication of glass reinforced prepregs. Test results and relative rankings of some of the flammability parameters are presented and the relationship of molecular structure, char yield, and flammability of the polymers are discussed. 
BIBLIOGRAPHIC DATA

SHEET (See in structions)

1. PUBLICATION OR REPORT NO.

NBSIR $85-3226$

August 1986

4. TITLE AND SUBTITLE

FIRE CHARACTERISTICS OF COMPOSITE MATERIALS -

A REVIEW OF THE LITERATURE

5. AUTHOR(S) James E. Brown, Joseph J. Loftus, Richard A. Dipert

6. PERFORMING ORGANIZATION (If joint or other than NBS, see instructions)

7. Contract/Grant No.

NATIONAL BUREAU OF STANDARDS

U.S. DEPARTMENT OF COMMERCE

8. Type of Report \& Period Covered

GAITHERSBURG, MD 20899

9. SFONSORING ORGANIZATION NAME AND COMPLETE ADDRESS (Street, City state, ZIP)

U. S. Department of the Navy

Naval Sea Systems Command (NAVSEA 05R25)

Washington, DC

10. SUPPLEMENTARY NOTES

[Document describes a computer program; SF-185, FIPS Software Summary, is attached.

11. ABSTRACT (A 200-word or less factual summary of most significant information. If document includes a significant bibliography or literature survey, mention it here)

A review is presented of the open literature concerning fire tests of composite materials which may be considered for use in U.S. Navy shipboard structures and installations. Results obtained for thermoplastic resins, thermoset resins, and composite structures are summarized from standard test methods. The methods include tests for limiting oxygen index, smoke production, flame spread, fire endurance, and also from measurements of polymer properties, including differential scanning calorimetry and thermogravimetric analysis. Typical criteria used by various investigators for ranking materials are discussed, and the material rankings based on test results are given. Data from non-standard tests designed to measure fire performance are also discussed. A detailed review of data and results of tests for selected references is given. Finally, recommendations are made for test developments and for the future direction of the U.S. Navy's fire evaluation program for composites and related materials intended for shipboard use.

12. KEY WORDS (Six to twelve entries; alphabetical order: copitalize only proper names; and separate key words by semicolons) composite materials: fire tests: flammab1lity; fiberglass resins: reinforced plastics: thermoplastic resins: thermosetting resins

13. AVAILABILITY

$\mathrm{X}$ Unlimited

For Official Distribution. Do Not Release to NTIS

Order From Superintendent of Documents, U.S. Government Printing Office, Washington, DC 20402.

$\left[_{-}^{X}\right.$ ) Order From National Technical Information Service (NTIS), Springfield, VA 22161
14. NO. OF

PRINTED PAGES

15. Price 

